CENDEKIA, Vol. 11, No. 2, Oktober 2017

p ISSN: 1978 2098; e -ISSN: 2407 8557

Http://cendekia.pusatbahasa.or.id; Email: cendekiaoslo@gmail.com

Center of Language and Culture Studies, Surakarta, Indonesia

Yuliananingsih. 2017. Pengaruh Model Pembelajaran Make a Match dan Motivasi

Terhadap Prestasi Belajar IPS Siswa SMPN 1 Karangploso. Cendekia, (2017), 11(2): 235 248.

\title{
PENGARUH MODEL PEMBELAJARAN MAKE A MATCH \\ DAN MOTIVASI TERHADAP PRESTASI BELAJAR IPS SISWA SMPN 1 KARANGPLOSO
}

\author{
Yuliananingsih \\ SMP Negeri 1 Karangploso - Kabupaten Malang \\ yuliananingsih59523@gmail.com
}

\begin{abstract}
This experimental research examines: (1) a significant influence of "make a match" model to attainment in IPS course of the students of SMPN 1 Karangploso; (2) a significant influnce of motivation model on the achievement IPS course; and (3) a significant influence between the type of "make a match" model and motivation model on the accomplishment of IPS course. The sample of this reseach was the 98 students of IX grade at SMPN 1 Karangploso Malang. The research revealed that: (1) "the make a match" learning model significantly influences learning achievement of IPS course of the students of SMPN 1 Karangploso; (2) motivation model significantly affects learning achievement of IPS, and (3) "the make a match" learning model and motivation model significantly influence achievement of IPS course.
\end{abstract}

Keywords: cooperative learning, motivation, achievement

Prestasi belajar merupakan salah satu faktor penilaian otentik dalam menentukan keberhasilan pembelajaran. Prestasi adalah hasil dari suatu kegiatan yang telah dikerjakan diciptakan baik secara individu maupun secara kelompok (Djamarah, 1994:19). Ada beberapa faktor yang memengaruhi prestasi belajar, antara lain kecedersan/intelegensi, bakat, minat dan motivasi.

Motivasi merupakan syarat mutlak dalam belajar. Suprijono (2011:162) menjelaskan bahwa terdapat korelasi signifikan antara motivasi dan belajar Motivasi belajar merupakan kekuatan yang mendorong atau memengaruhi individu untuk bertindak hingga mengalami perubahan perilaku. Bukan hanya hasil belajar yang berubah, tetapi efektivitas pembelajaran juga meningkat.

Motivasi tersebut dapat diperoleh dari inovasi pembelajaran. Guru harus mampu membangkitkan motivasi belajar siswa melalui inovasi-inovasi pembelajaran. Hal ini dikarenakan guru berperan sebagai perancang pembelajaran, pengelola pembelajaran, penilai hasil pembelajaran peserta didik, pengarah pembelajaran dan pembimbing peserta didik.

Ilmu Pengetahuan Sosial (IPS) merupakan salah satu mata pelajaran yang tidak masuk dalam Ujian Nasional (UN). Hal ini membuat siswa sering meremehkan pelajaran tersebut. Sikap siswa tersebut tentu membuat hasil belajar siswa rendah. Padahal, ilmu ini sangat penting bagi siswa ketika berada di masyarakat. Sumaatmadja 
(1980: 8-9) mengemukakan bahwa Pendidikan IPS adalah suatu penyederhanaan disiplin ilmu-ilmu sosial, ideologi negara dan displin ilmu lainnya serta masalahmasalah sosial terkait, yang diorganisasikan dan disajikan secara ilmiah. Pembelajaran IPS dilakukan secara terpadu dengan mengaplikasikan teori dalam praktik nyata di masyarakat.

Berdasarkan pengamatan pada siswa kelas IX SMP Negeri 1 Karangploso, guru telah melakukan proses pembelajaran menggunakan diskusi kelompok maupun tanya jawab. Namun, tanya jawab hanya didominasi siswa tertentu yang secara kuantitatif minim atau 5 siswa $(16,67 \%)$. Sementara itu, siswa yang lain 25 siswa $(83,33 \%)$ pasif. Hal ini juga berlangsung ketika diskusi dalam kelompok. Ketua kelompok sebagai siswa yang menjawab, menulis, dan menyajikan hasil sedangkan teman lainnya cenderung pasif. Hal ini menyebabkan hasil belajar siswa dalam kelompok bagus, tetapi hasil tes individu jelek. Beberapa siswa saja yang akif melakukan siswa yang lain cenderung hanya diam, siswa kurang aktif, siswa malu dan takut memberikan jawaban yang salah dan sebagaian siswa juga sulit melakukan adaptasi dan kerjasama. Ini menunjukkan kurangnya motivasi dan minat siswa dalam mata pelajaran IPS Terpadu yang berpengaruh terhadap hasil belajar siswa.

Salah satu model pembelajaran yang dimanfaatkan untuk memotivasi siswa, yaitu model pembelajaran kooperatif. Model pembelajaran kooperatif merupakan hal yang sangat penting dalam menunjang interaksi antara siswa dengan siswa, maupun antara siswa dengan guru. Slavin dalam Solihatin (2009:4) menyatakan bahwa cooperative learning adalah suatu model pembelajaran di mana siswa belajar dan bekerja sama dalam kelompok-kelompok kecil secara kolaboratif yang anggotanya terdiri dari 4 sampai 6 orang, dengan struktur kelompoknya yang bersifat heterogen. Selanjutnya dijelaskan pula, keberhasilan dari kelompok tergantung pada kemampuan dan aktivitas anggota kelompok, baik secara individual maupun secara kelompok. Model pembelajaran kooperatif ada beberapa, salah satunya tipe make a match.

Model pembelajaran make a match digunakan untuk mengatasi permasalahan siswa dalam meningkatkan motivasi belajar. Metode make a match atau mencari pasangan merupakan salah satu alternatif yang dapat diterapkan kepada siswa. Penerapan metode ini dimulai dari teknik yaitu siswa disuruh mencari pasangan kartu yang merupakan jawaban/soal sebelum batas waktunya, siswa yang dapat mencocokkan kartunya diberi poin (Ramadhan, 2008). Model pembelajaran make a match adalah suatu model pembelajaran dimana guru mempersiapkan kartu yang berisi persoalan permasalahan dan kartu yang berisi jawabannya, setiap siswa mencari dan mendapatkan sebuah kartu soal dan berusaha menjawabnya, setiap siswa mencari kartu jawaban yang cocok dengan persoalannya siswa. Siswa yang benar mendapat nilai-reward, kartu dikumpul lagi dan dikocok, untuk babak berikutnya pembelajaran seperti babak pertama, penyimpulan, evaluasi dan refleksi (Sudrajat, 2009).

Fatmawati (2012) melakukan penelitian yang menyimpulkan bahwa pembelajaran IPS dengan menggunakan model make a match dapat meningkatkan hasil belajar siswa. Hal ini ditunjukkan dengan hasil belajar siswa pada tes awal nilai rata-rata yang diperoleh siswa adalah 16,67\% (sebelum diberi tindakan) menjadi 44,45\% (setelah diberi tindakan siklus I) dan $95,71 \%$ (siklus II). Hal ini menunjukkan bahwa penerapan model pembelajaran make a match dapat meningkatkan hasil belajar siswa. 
Hardiana, dkk (2013) melakukan penelitian terkait pengaruh model pembelajaran make a match terhadap hasil belajar IPS. Berdasarkan hasil analisis diketahui bahwa thitung (5.022) > ttabel 2.04 dan taraf signifikansi sebesar 0.682 . Berdasarkan hasil tersebut dapat disimpulkan bahwa model pembelajaran make a match berpengaruh secara signifikan terhadap hasil belajar kognitif dan taraf signifikansi dari pengaruh penggunaan model pembelajaran make a match kuat terhadap hasil belajar kognitif.

Persamaan kedua penelitian dengan penelitian ini terletak pada penggunaan model pembelajaran tipe make a match. Sementara itu, perbedaan kedua penelitian tersebut dengan penelitian ini terletak pada rancangan penelitian. Penelitian Fatmawati menggunakan desain penelitian tindakan kelas, sedangkan penelitian Hardiana dkk. hanya menggunakan satu variabel pembanding. Penelitian ini memadukan dua variabel pembanding yaitu model pembelajaran make a match dan motivasi belajar.

Berdasarkan uraian tersebut, guru perlu mengetahui pengaruh motivasi dan pemanfaatan model pembelajaran terhadap prestasi belajar agar dapat dimanfaatkan sebagai bahan mendesain pembelajaran secara terpadu. Oleh karena itu, peneliti mengadakan penelitian berjudul "Pengaruh Penerapan Model Pembelajaran Make a Match dan Motivasi Belajar terhadap Prestasi Belajar IPS Siswa Kelas IX SMP Negeri 1 Karangploso".

\section{METODE}

Penelitian ini menggunakan desain penelitian deskriptif korelasional. Penelitian deskriptif (descriptive research) dimaksudkan untuk eksplorasi klarifikasi masalah mengenai suatu fenomena atau kenyataan sosial dengan jalan mendeskripsikan sejumlah variabel yang berkenaan dengan masalah dan unit yang diteliti (Latipun, 2002:5). Sementara itu, penelitian korelasi ialah penelitian yang bertujuan untuk menemukan ada tidaknya hubungan dan seberapa erat hubungan tersebut, serta berarti atau tidaknya hubungan itu (Arikunto, 2006:270). Prinsip penelitian korelasi yaitu peneliti menghubungkan sejumlah variabel, tetapi tidak melakukan manipulasi terhadapnya (Latipun, 2002:5). Berdasarkan hipotesis dalam rancangan penelitian ini ditentukan variabel-variabel yang dipergunakan dalam penelitian.

Dalam suatu penelitian, variabel merupakan suatu yang sangat penting. Suryabrata (2012:25) menyatakan bahwa variabel dapat diartikan segala sesuatu yang menjadi objek pengamatan peneliti atau faktor-faktor yang berperan dalam peristiwa atau gejala yang akan diteliti. Variabel tersebut diolah dalam paradigma. Menurut Sugiyono (2012:42) paradigma merupakan pola pikir yang menunjukkan hubungan antara variabel yang akan diteliti sekaligus mencerminkan jenis dan jumlah rumusan masalah yang perlu dijawab melalui penelitian. Penelitian ini menggunakan paradigma ganda dengan dua variabel bebas, dan satu variabel terikat. Variabel terikat merupakan variabel yang dipengaruhi atau menjadi akibat karena adanya variabel bebas (Setyosari, 2010:164). Variabel terikat pada penelitian ini yaitu prestasi belajar. Sementara itu, variabel bebas adalah variabel yang memengaruhi atau menjadi sebab perubahan variabel terikat (Setyosari, 2010:165). Variabel bebas dalam penelitian ini yaitu model pembelajaran make a match dan motivasi belajar. Perhatikan bagan penentuan variabel berikut. 


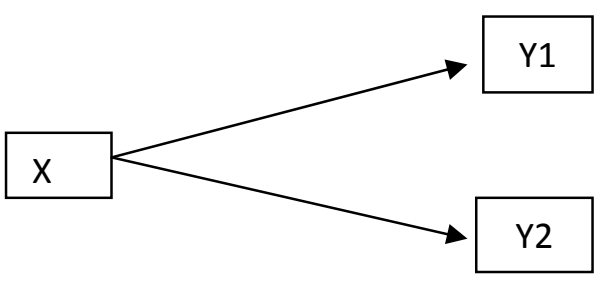

Keterangan:

$\mathrm{X}$ : variabel terikat

Y1 : variabel bebas, model pembelajaran make a match

Y2 : variabel bebas, motivasi belajar

Populasi dalam penelitian ini adalah seluruh kelas IX A sampai IX H di SMP Negeri 1 Karangploso tahun ajaran 2015/2016 yang berjumlah 8 kelas. Teknik pengambilan sampel pada penelitian ini menggunakan Proporsional random sampling yaitu dari jumlah populasi ditentukan jumlah sampel sebagai obyek penelitian, pengambilan sampel dilakukan secara merata ke setiap kelas sehingga semua responden mempunyai kesempatan yang sama sebagai sampel penelitian. Salah satu metode yang digunakan untuk menentukan jumlah sampel adalah rumus Slovin :

$$
\mathrm{n}=\frac{N}{1+N \alpha 2}
$$

Dimana $: \mathrm{n}=$ Jumlah sampel

$\mathrm{N}=$ Jumlah populasi

$\alpha=$ Batas toleransi kesalahan (error Tolerance)

$$
\mathrm{n}=\frac{130}{1+130(0,05) 2}=98
$$

Dari rumus di atas, 130 jumlah populasi yang ada diambil sampelnya yaitu sejumlah 98 siswa, jadi untuk setiap kelas diambil 24 / 25 siswa.

Menurut Sugiyono (2012:148) instrumen penelitian adalah suatu alat yang digunakan untuk mengukur fenomena alam maupun sosial yang di amati. Instrumen penelitian yang digunakan dalam peneletian ini adalah instrumen untuk mengukur kemampuan kognitif siswa yaitu tes kemampuan kognitif (tes objektif tipe pilihan ganda), sesuai materi yang telah ditentukan yang diberikan kepada siswa pada awal dan di setiap akhir pertemuan pada mata pelajaran IPS Terpadu. Pengumpulan data dilakukan pada saat pembelajaran berlangsung. Pengambilan data yaitu dengan teknik pokok dan teknik penunjang. Teknik pokok terdiri dari tes, sedangkan teknik penunjang dengan dokumentasi dan observasi.

Teknik analisis data menggunakan analisis regresi berganda. Sebelum dilakukan analisis regresi, terlebih dahulu dilakukan uji asumsi klasik yang terdiri dari uji normalitas, uji multikolinearitas, dan uji heteroskedastitas. Hasil analisis diinterpretasikan dan disimpulkan serta diberikan saran. Analisis data tersebut menggunakan SPSS 16.00 for windows. 


\section{HASIL DAN BAHASAN}

\section{Analisis Instrumen Penelitian}

Pengumpulan data dalam penelitian ini dilakukan terhadap 98 siswa SMPN 1 Karangploso. Selain menggunakan instrumen kuesioner dalam pengumpulan data, peneliti juga mengadakan observasi langsung. Sebagaimana telah disebutkan dalam bab sebelumnya, untuk pengujian reliabilitas dan validitas, maka terlebih dahulu diadakan pre-test yang diperoleh nilai rata rata 66,50 sedangkan KKM 75. Dari hasil pre-test tersebut kemudian dilakukan pengujian statistik terhadap reliabilitas dan validitas dari instrumen kuesioner yang dipakai.

\section{Uji Reliabilitas terhadap hasil Questionnaire dengan Cronbach's Alpha}

Dari hasil pengolahan komputer dengan program SPSS 16 untuk uji reliabilitas (reliability Analysis - Scale /Alpha), maka data questionnaire secara keseluruhan menghasilkan Cronbach 's Alpha Coefficient sebagai berikut:

Tabel 1

Pengujian Validitas dan Reliabilitas Instrumen Penelitian

\begin{tabular}{cccc}
\hline Latent Variable & $\begin{array}{c}\text { Item to Total } \\
\text { Correlation }\end{array}$ & $\begin{array}{c}\text { Cronbach's Alpha } \\
\text { Coefficient }\end{array}$ & Keterangan \\
\hline $\begin{array}{c}\text { Metode } \\
\text { Pembelajaran }\end{array}$ & $\mathbf{0 , 5 4 1}$ & $\mathbf{0 , 7 9 9}$ & Valid dan Reliabel \\
\hline Motivasi Belajar & $\mathbf{0 , 5 2 4}$ & $\mathbf{0 , 7 9 6}$ & Valid dan Reliabel \\
\hline
\end{tabular}

Koefisien Cronbach's Alpha menunjukkan konsistensi internal reliabilitas dari observed Variables, sedangkan item to total correlation dihitung untuk memperbaki ukuran - ukuran dan mengeliminasi item - item yang keberadaannya akan memperkecil koefisien cronbach's alpha yang dihasilkan. Eiminasi pada item to total correlation diberlakukan pada indikator yang nilainya $<0,5$ (Purwanto, 2003). Jadi nilai dari setiap indikator pada tabel item to total correlation di atas menunjukkan bahwa tidak ada indikator yang harus dieliminasi karena semua nilainya $>0,5$.

\section{Uji Validitas Instrumen Penelitian}

Sebuah instrumen dikatakan valid jika mampu mengukur apa yang diinginkan serta dapat mengungkap data dari variabel yang diteliti secara lengkap (Hadi, 1990). Dalam pengujian validitas instrumen penelitian, digunakan teknik korelasi pearson. Suatu penelitian dapat dikatan valid jika memiliki nilai koefisien korelasi setiap item dengan korelasi totalnya $\geq 0,4$.

\section{Uji Reliabilitas Instrumen Penelitian}

Suatu instrumen penelitian dikatakan reliabel apabila nilai koefisien alpha Cronbach $\geq 0,06$ (Nurgiyantoro, 2004). Hasil pengujian reliabel dan validitas yang 
terlihat pada tabel 4.3, memberikan konfirmasi bahwa semua indikator yang dikonversikan ke dalam pernyataan dalam quetioner yang dipakai sebagai instrumen penelitian dinyatakan valid dan reliabel.

Tabel 2

Ringkasan Hasil Regresi Linier Berganda

Coefficients $^{\mathrm{a}}$

\begin{tabular}{|c|c|c|c|c|c|c|}
\hline & & \multicolumn{2}{|c|}{$\begin{array}{l}\text { Unstandardized } \\
\text { Coefficients }\end{array}$} & \multirow{2}{*}{$\begin{array}{l}\text { Standardized } \\
\text { Coefficients } \\
\text { Beta }\end{array}$} & \multirow[b]{2}{*}{$\mathrm{T}$} & \multirow[b]{2}{*}{ Sig. } \\
\hline \multicolumn{2}{|c|}{ Model } & B & Std. Error & & & \\
\hline \multirow[t]{3}{*}{1} & (Constant) & 50.886 & 4.880 & & 10.427 & .000 \\
\hline & Metode & .178 & .095 & .166 & 1.874 & .064 \\
\hline & Motivasi & .351 & .066 & .472 & 5.337 & .000 \\
\hline
\end{tabular}

a. Dependent Variable: Prestasi

$$
\mathrm{Y}=\mathbf{5 0 , 8 8 6}+\mathbf{0 , 1 7 8} \mathrm{X} 1+\mathbf{0 , 3 5 1} \mathrm{X} 2+\mathrm{e}
$$
berikut.

Dari tabel 2 di atas dapat dibuat persamaan regresi linier berganda sebagai

Hasil regresi menunjukkan arah pengaruh masing-masing variabel bebas terhadap perubahan prestasi belajar siswa kelas IX. Model pembelajaran (X1), Motivasi belajar (X2) mempunyai pengaruh positif terhadap prestasi belajar siswa kelas IX pada mata pelajaran IPS (Y). Nilai koefisien regresi model pembelajaran sebesar 0,178 menunjukkan bahwa dengan asumsi variabel lain konstan, meningkatnya model pembelajaran sebesar 1 point akan mengakibatkan peningkatan belajar siswa sebesar 0,178 point. Nilai koefisien regresi motivasi belajar sebesar 0,351 berarti bahwa dengan asumsi variabel lain konstan, meningkatnya motivasi sebesar 1 point akan mengkibatkan meningkatnya prestasi belajar siswa sebesar 0,351 point.

Hal diatas menunjukkan bahwa penerapan metode cooperative learning tipe make a match dapat meningkatkan prestasi belajar siswa, namun hasilnya lebih kecil dibanding dengan penelitian yang dilakukan oleh Supriyono, Puji Nugraheni yang berjudul "Eksperimentasi pembelajaran matematika menggunakan model cooperative learning tipe make a match terhadap prestasi belajar materi segi empat siswa kelas VII SMP Negeri 1 Mirit Kebumen Tahun pelajaran 2011-2012.

Hasil analisis menunjukkan bahwa rata-rata data awal kelompok eksperimen sebesar 54,50 rata-rata tes akhir (post test) kelompok eksperimen sebesar 70,655. Sedangkan rata-rata data awal kelompok kontrol sebesar 54,207, rata-rata tes akhir (post test) kelompok kontrol sebesar 62,08. Dari hasil analisis data diperoleh nilai thitung $=$ 2,3792 . Sedangkan pengujian dilakukan dengan menggunakan uji t pihak kanan dengan taraf kesalahan 5\% didapat ttabel $=1,6706$ sehingga nilai thitung lebih dari ttabel $(2,3792>1,6706)$ dan dapat disimpulkan bahwa Ha diterima dan Ho ditolak sehingga prestasi belajar siswa yang menggunakan model pembelajaran make a match lebih baik 
daripada prestasi belajar siswa dengan metode konvensional pada materi segiempat siswa kelas VII SMP Negeri 1 Mirit Kebumen tahun pelajaran 2011/2012.

Tabel 3

Model Summary

\begin{tabular}{|l|r|r|r|r|}
\hline Model & \multicolumn{1}{|c|}{$\mathrm{R}$} & R Square & $\begin{array}{c}\text { Adjusted R } \\
\text { Square }\end{array}$ & $\begin{array}{c}\text { Std. Error of } \\
\text { the Estimate }\end{array}$ \\
\hline 1 & $.460^{\mathrm{a}}$ & .211 & .195 & 4.70423 \\
\hline
\end{tabular}

a. Predictors: (Constant), Motivasi, Metode

Tabel 3 menunjukkan nilai koefisien determinasi $\left(\mathrm{R}^{2}\right)$ sebesar 0,211. Sebelum hasil regresi diatas dilakukan sebagai pemerkira, maka perlu dilakukan pengujian terhadap gejala multikolinieritas, heteroskedasitas dan autokorelasi terlebih dahulu.

\section{Pengujian Asumsi Multikolinieritas}

Untuk mengetahui ada atau tidaknya kasus multikolinieritas, dapat dilihat dari nilai korelasi antar variabel bebas.

Tabel 4

Coefficient Correlations $^{\mathrm{a}}$

\begin{tabular}{|c|c|c|c|c|}
\hline \multicolumn{3}{|c|}{ Model } & \multirow{2}{*}{$\frac{\text { Motivasi }}{1.000}$} & \multirow{2}{*}{$\begin{array}{l}\text { Metode } \\
-.066\end{array}$} \\
\hline 1 & Correlations & Motivasi & & \\
\hline & & Metode & -.066 & 1.000 \\
\hline & \multirow[t]{2}{*}{ Covariances } & Motivasi & .004 & .000 \\
\hline & & Metode & .000 & .009 \\
\hline
\end{tabular}

a. Dependent Variable: Prestasi

Dari hasil pengujian pada tabel 4 menunjukan bahwa koefisien antar variabel bebas, tidak melebihi nilai kritis. Dengan demikian dapat disimpulkan tidak terjadi gejala multikolinieritas di antara variabel bebas tersebut.

\section{Pengujian Asumsi Heteroskedasitas}

Untuk mendeteksi ada tidaknya kasus heteroskedasitas dilakukan dengan metode korelasi Rank Spearmen dan uji t. 


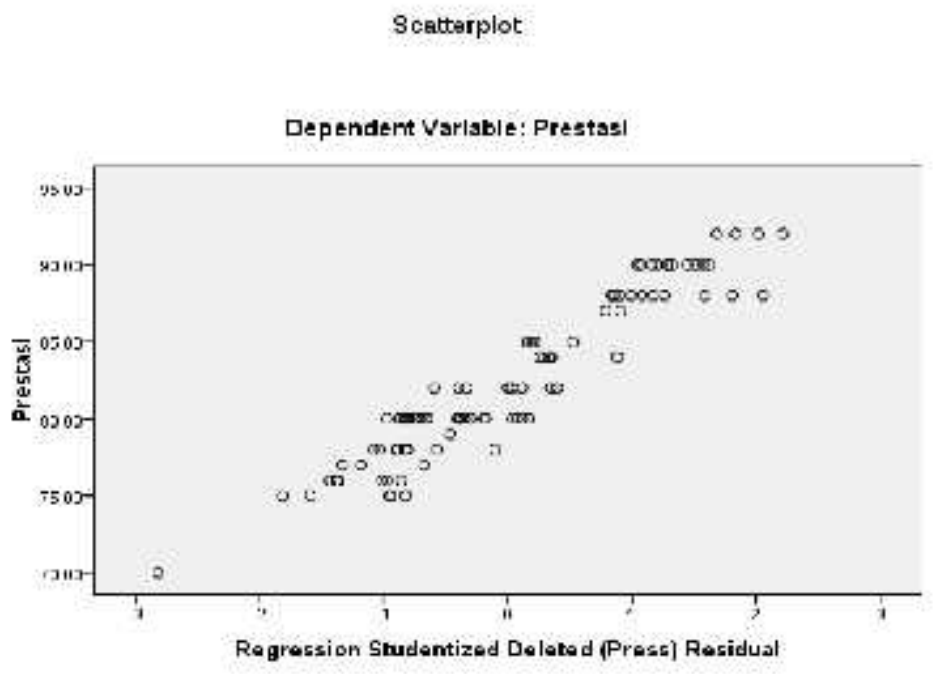

Berdasarkan grafik tersebut dapat dilihat bahwa titik - titik tersebar di sekitar garis nol dan tidak membentuk pola tertentu sehingga dapat disimpulkan tidak terdapat gejala heteroskedasitas.

\section{Pengujian Asumsi Autokorelasi}

Untuk mendeteksi adanya geala autokorelasi digunakan uji d (Durbin Watson test).

\section{Tabel 5}

Model Summary ${ }^{\mathrm{b}}$

\begin{tabular}{|l|l|}
\hline Model & Durbin-Watson \\
\hline 1 & $1.568^{\mathrm{a}}$ \\
\hline
\end{tabular}

a. Predictors: (Constant), Motivasi,

Metode

b. Dependent Variable: Prestasi

Nilai d yang diperoleh adalah 1,568, sedangkan nilai dtabel pada tingkat signifikan $\alpha=5 \%$ dengan variabel bebas $\mathrm{k}=2$ diperoleh nilai $\mathrm{d} 1=1,49$ dan $\mathrm{du}=1,68$. Dari angka - angka tersebut dapat dilihat bahwa nilai d terdapat pada daerah:

$$
\begin{aligned}
& \mathrm{du}<\mathrm{d}<3-\mathrm{du} \\
& 1,49<1,568<1,68
\end{aligned}
$$

Nilai Durbin Watson sebesar 1,568 berada pada daerah penolakan Ho dimana $\mathrm{d}(1,568)>\mathrm{du}(1,49)$ dan $\mathrm{d}(1,568)<3-\mathrm{du}$, berarti tidak terjadi gejala autokorelasi positif maupun negatif. Berdasarkan hasil pengujian statistik, dapat disimpulkan bahwa model persamaan dalam penelitian terhindar dari gejala multikolinieritas, heteroskedastitas dan autokorelasi. 


\section{Pengujian Hipotesis}

Pengujian hipotesis bertujuan untuk membuktikan kebenaran hipotesis yang diajukan. Apabila kebenaran hipotesis tersebut dapat dibuktikan, maka akan dilaukan pembahasan untuk menganalisis lebih lanjut hasil yang diperoleh dari model regresi linier berganda.

\section{Pengujian Hipotesis pengaruh variabel bebas secara simultan}

Uji F digunakan untuk mengetahui apakah kedua variabel bebas secara simultan mempunyai pengaruh yang signifika terhadap variabel tidak bebasnya.

Tabel 6

ANOVA ${ }^{b}$

\begin{tabular}{|c|c|c|c|c|c|c|}
\hline \multicolumn{2}{|c|}{ Model } & $\begin{array}{l}\text { Sum of } \\
\text { Squares }\end{array}$ & Df & Mean Square & $\mathrm{F}$ & Sig. \\
\hline \multirow[t]{3}{*}{1} & Regression & 734.178 & 2 & 367.089 & 17.926 & $.000^{\mathrm{a}}$ \\
\hline & Residual & 1945.373 & 95 & 20.478 & & \\
\hline & Total & 2679.551 & 97 & & & \\
\hline
\end{tabular}

a. Predictors: (Constant), Motivasi, Metode

b. Dependent Variable: Prestasi

Hasil pengujian menunjukkan bahwa nilai $F$ hitung yang diperoleh sebesar 17,926 lebih besar jika dibandingkan dengan $F$ tabel sebesar 3,07. Pada tingkat $\alpha=0,05$ (tingkat keyakinan 95\%) dan tingkat signifikansi F 0,00 berarti Ho ditolah dan $\mathrm{H} 1$ diterima. Dengan demikian dapat dinyatakan bahwa ada pengaruh signifikan yang ditimbulkan oleh metode pembelajaran dan motivasi belajar secara simultan berpengaruh terhadap prestasi belajar siswa.

\section{Pengujian Hipotesis Pengaruh Tiap Variabel Bebas secara Individual \\ Tabel 7}

Coefficients $^{\mathrm{a}}$

\begin{tabular}{|c|c|c|c|c|c|c|}
\hline \multirow{2}{*}{\multicolumn{2}{|c|}{ Model }} & \multicolumn{2}{|c|}{$\begin{array}{l}\text { Unstandardized } \\
\text { Coefficients }\end{array}$} & \multirow{2}{*}{$\begin{array}{c}\text { Standardized } \\
\text { Coefficients } \\
\text { Beta }\end{array}$} & \multirow[b]{2}{*}{$\mathrm{t}$} & \multirow[b]{2}{*}{ Sig. } \\
\hline & & B & Std. Error & & & \\
\hline 1 & (Constant) & 50.886 & 4.880 & & 10.427 & .000 \\
\hline & Metode & .178 & .095 & .166 & 1.874 & .064 \\
\hline & Motivasi & .351 & .066 & .472 & 5.337 & .000 \\
\hline
\end{tabular}

a. Dependent Variable: Prestasi

Berdasarkan hasil perhitungan di atas, dapat diketahui besarnya nilai t hitung dan $t$ tabel dari masing - masing variabel bebas sebagai berikut:

a. Besarnya t hitung untuk variabel metode pembelajaran $(\mathrm{X} 1)=1,874$ lebih besar dari t tabel 1,658 pada tingkat signifikansi 0,05 berarti Ho ditolak dan H1 diterima. 
Hal tersebut menunjukkan bahwa variabel metode pembelajaran (X1) mempunyai pengaruh yang signifikan terhadap prestasi belajar siswa.

b. Besarnya t hitung untuk variabel motivasi belajar $(X 2)=5,337$ lebih besar dari pada $\mathrm{t}$ tabel 1,658, sehingga Ho ditolak dan $\mathrm{H} 1$ diterima. Hasil tersebut menunjukkan bahwa variabel motivasi belajar mempunyai pengaruh signifikan terhadap prestasi belajar siswa.

\section{BAHASAN}

\section{Pengaruh Antar Variabel}

Hasil uji hipotesis secara singkat menunjukkan hal - hal sebagai berikut:

1. Terbukti bahwa metode coopertive learning tipe make a match secara signifikan berpengaruh terhadap prestasi belajar siswa kelas IX mata pelajaran IPS.

2. Terbukti bahwa motivasi belajar secara signifikan berpengaruh terhadap prestasi belajar siswa kelas IX mata pelajaran IPS.

3. Terbukti bahwa metode coopertaive learning tipe make a match dan motivasi belajar yang dilakukan bersama - sama secara signifikan berpengaruh terhadap prestasi belajar siswa kelas IX mata pelajaran IPS.

\section{Pengaruh Model Pembelajaran make a match terhadap Prestasi Belajar}

Hasil penelitian ini menunjukkan bahwa dengan menggunakan metode cooperative learning tipe make a macth pada akhirnya mampu meningkatkan prestasi belajar siswa. Temuan ini membuktikan bahwa dengan penggunaan metode cooperative learning tipe make a macth yang inovatif dan menyenangkan akan sangat berpengaruh terhadap prestasi belajar siswa. Dengan penerapan metode cooperative learning tipe make a macth akan berdampak pada kegiatan belajar siswa sehingga berpengaruh pada meningkatnya prestasi belajar siswa pada mata pelajaran IPS. Hal ini terlihat dari hasil rekapitulasi data kuisioner penerapan metode cooperative learning tipe make a match sebagai berikut :

\section{Tabel 8}

Rekap hasil data kuisioner

Model pembelajaran make a match

\begin{tabular}{|c|c|c|c|c|c|c|c|c|}
\hline $\mathrm{NO}$ & PERNYATAAN & 1 & 2 & 3 & 4 & 5 & $\begin{array}{l}\text { setuju } \\
\text { \&sangat } \\
\text { setuju }\end{array}$ & prosentase \\
\hline 1 & $\mathrm{X} 1.1$ & 0 & 0 & 2 & 53 & 43 & 96 & $97,96 \%$ \\
\hline 2 & $\mathrm{X} 1.2$ & 0 & 0 & 5 & 67 & 27 & 94 & $95,92 \%$ \\
\hline 3 & $\mathrm{X} 1.3$ & 0 & 0 & 6 & 76 & 16 & 92 & $93,88 \%$ \\
\hline 4 & $\mathrm{X} 1.4$ & 0 & 0 & 7 & 56 & 36 & 92 & $93,88 \%$ \\
\hline 5 & $\mathrm{X} 1.5$ & 0 & 0 & 6 & 39 & 54 & 93 & $94,91 \%$ \\
\hline 6 & X1.6 & 0 & 1 & 11 & 51 & 35 & 86 & $87,76 \%$ \\
\hline 7 & X1.7 & 0 & 1 & 10 & 62 & 25 & 87 & $88,78 \%$ \\
\hline 8 & $\mathrm{X} 1.8$ & 0 & 1 & 8 & 64 & 25 & 89 & $90,83 \%$ \\
\hline
\end{tabular}


Berdasarkan data tersebut, ada beberapa pernyataan berkaitan dengan persentase penerapan model pembelajaran make a match.

1. Pernyataan pembelajaran dengan menerapkan model pembelajaran make a match sangat menyenangkan mendapatkan tanggapan 94 atau 97,96 \% siswa setuju dan sangat setuju.

2. Pernyataan penerapan model pembelajaran make a match sudah sesuai dengan materi pembelajaran, mendapat tanggapan 94 siswa atau 95,92\% setuju dan sangat setuju.

3. Pernyataan penerapan model pembelajaran make a match sudah sesuai dengan tujuan yang direncanakan, hal ini ditanggapi oleh 92 siswa atau 93,88\% setuju dan sangat setuju.

4. Pernyatan dengan model pembelajaran make a match saya dapat belajar dengan mudah, hal ini ditanggapi oleh 92 siswa atau 93,88\% setuju dan sangat setuju.

5. Pernyataan pembelajaran dengan model pembelajaran make a match mengajarkan untuk bekerjasama dengan teman secara penuh, mendapat tanggapan 93 siswa atau 94,91\% setuju dan sangat setuju.

6. Pernyataan pembelajaran dengan model pembelajaran make a match membuat kami ada ketergantungan secara positif dengan teman,ditanggapi sebanyak 86 siswa atau $87,76 \%$ yang setuju dan sangat setuju.

7. Pernyataan dengan penerapan model pembelajaran make a match saya diberi kesempatan untuk menentukan pilihan, mendapat tanggapan 87 siswa atau $88,78 \%$ yang setuju dan sangat setuju.

8. Pernyataan dengan model pembelajaran make a match saya merasa terbantu dalam belajar, mendapat tanggapan 89 siswa atau 90,83\% yag setuju dan sangat setuju. Dan setelah diambil rata ratanya $92,99 \%$ siswa memberikan tanggapan setuju dan sangat setuju.

\section{Pengaruh Motivasi Belajar terhadap Prestasi Belajar}

Hasil penelitian ini menunjukkan bahwa dengan pemberian motivasi belajar kepada siswa akan sangat mempengaruhi pemahaman siswa pada akhirnya mampu meningkatkan prestasi belajar siswa. Temuan ini membuktikan bahwa dengan pemberian motivas belajar yang kuat akan sangat berpengaruh terhadap prestasi siswa. Hal ini sesuai dengan pendapat dari Sardiman (2008) yang menyatakan bahwa siswa yang memiliki motivasi kuat, akan mempunyai banyak energi untuk melakukan kegiatan belajar. Dengan motivasi yang kuat akan berdampak pada kegiatan belajar siswa sehingga berpengaruh pada meningkatnya prestasi belajar siswa pada mata pelajaran IPS. Dari hasil kuisioner dapat dilihat hasilnya sebagai berikut: 
Http://cendekia.pusatbahasa.or.id; Email: cendekiaoslo@gmail.com

Center of Language and Culture Studies, Surakarta, Indonesia

Yuliananingsih. 2017. Pengaruh Model Pembelajaran Make a Match dan Motivasi

Terhadap Prestasi Belajar IPS Siswa SMPN 1 Karangploso.

Cendekia, (2017), 11(2): 235 248.

Tabel 9

\section{Rekap data kuisioner}

Motivasi Belajar

\begin{tabular}{|c|c|c|c|c|c|c|c|c|}
\hline no & Pernyataan & 1 & 2 & 3 & 4 & 5 & $\begin{array}{l}\text { setuju } \\
\text { \&sangat } \\
\text { setuju }\end{array}$ & prosentase \\
\hline 1 & $\mathrm{X} 2.1$ & 0 & 1 & 4 & 32 & 61 & 93 & $94,90 \%$ \\
\hline 2 & $\mathrm{X} 2.2$ & 0 & 9 & 3 & 20 & 66 & 86 & $87,76 \%$ \\
\hline 3 & $\mathrm{X} 2.3$ & 0 & 7 & 6 & 47 & 38 & 85 & $86,73 \%$ \\
\hline 4 & $\mathrm{X} 2.4$ & 0 & 10 & 3 & 57 & 29 & 86 & $87,76 \%$ \\
\hline 5 & $\mathrm{X} 2.5$ & 0 & 9 & 3 & 36 & 50 & 86 & $87,77 \%$ \\
\hline 6 & $\mathrm{X} 2.6$ & 0 & 9 & 11 & 53 & 25 & 78 & $79,60 \%$ \\
\hline 7 & $\mathrm{X} 2.7$ & 0 & 0 & 7 & 54 & 37 & 91 & $92,86 \%$ \\
\hline 8 & $\mathrm{X} 2.8$ & 0 & 0 & 12 & 54 & 29 & 83 & $84,69 \%$ \\
\hline
\end{tabular}

Berdasarkan data tersebut, ada beberapa pernyataan sebagai berikut.

1. Pernyataan dengan berpikir yang berorientasi kemasa depan saya rajin belajar agar tercapai kinginan saya, mendapat tanggapan 93 siswa atau 94,90\% yang setuju dan sangat setuju.

2. Pernyataan kedua orang tua saya selalu bekerja dengan semangat yang tinggi, maka saya harus berusaha tekun belajar setiap hari agar bisa mendapatkan hasil yang lebih baik, mendapatkan tanggapan 86 siswa atau $87,76 \%$ yang setju dan sangat setuju.

3. Pernyatan saudara saya sangat rajin merangkum semua mata pelajaran yang diberikan disekolah,saya ingin rajin seperti mereka, mendapatkan tanggapan 85 siswa atau $86,73 \%$ ang setuju dan sangat setuju.

4. Bapak dan ibu guru memberikan pujian bila kami dapat berhasil memecahkan permasalahan ,hal itu membuat kami senang. Mendapat tanggapan 86 atau $87,76 \%$ yang setuju dan sangat setuju.

5. Bapak dan ibu guru juga memberikan teguran pada kami bila kami melakukan tindakan yang tidak sopan dan tidak baik, mendapat tanggapan 86 sisa atau 87,76\% yang setuju dan sangat setuju.

6. Saya sangat tertarik pada pembelajaran yang melibatkan seluruh siswa di kelas kami, mendpat tanggapan 78 siswa atau $79,60 \%$ yang setuju dan sangat setuju.

7. Gaya mengajar sebagian dari bapak dan ibu guru kami membuat kami bersemangat dalam pembelajaran, mendapat tanggapan 91 siswa atau 92,86\% yang setuju dan sangat setuju.

8. Banyak materi pembelajaran yang membuat kami untuk mempelajarinya lebih lanjut, mendapat tanggapan 83 siswa atau $84,69 \%$ yang setuju dan sangat setuju. Dan setelah diambil rata rata $87,76 \%$ siswa memberikan tanggapan setuju dan sangat setuju. 


\section{Pengaruh metode cooperative learning tipe make a match dan Motivasi belajar terhadap Prestasi Belajar}

Penelitian pengaruh metode cooperative learning tipe make a match dan motivasi belajar terhadap prestasi belajar siswa Kelas IX SMPN 1 Karangploso Kabupaten Malang, didapati temuan penelitian yang diuraikan di bawah ini:

Penelitian ini menemukan pengaruh antara metode cooperative learning tipe make a match dan motivasi belajar terhadap prestasi belajar siswa Kelas IX SMPN 1 Karangploso Kabupaten Malang. Hal ini menunjukkan bahwa penerapan metode cooperative learning tipe make a match dan motivasi belajar berpengaruh besar terhadap prestasi belajar siswa Kelas IX SMPN 1 Karangploso Kabupaten Malang. Dengan menerapkan metode pembelajaran yang kreatif dan menyenangkan dan pemberian motivasi belajar maka lambat laun prestasi belajar siswa pasti akan meningkat. Temuan tersebut dapat dilihat dengan peningkatan rata - rata pada pelaksanaan UAS mata pelajaran IPS kelas IX dari 78,5 menjadi 81,3. Temuan ini hendaknya diperhatikan guru, kepala sekolah, serta pihak - pihak terkait untuk mendukung upaya sekolah meningkatkan prestasi belajar siswa.

\section{SIMPULAN}

Berdasarkan hasil analisis dan uji hipotesis penelitian, dapat disimpulkan beberapa hal sebagai berikut.

1. Asumsi multikolinieritas, asumsi uji heterokedastisitas terbukti tidak ada masalah.

2. Penerapan model pembelajaran make a match secara signifikan berpengaruh terhadap prestasi belajar siswa kelas IX SMP Negeri 1 Karangploso dengan koefisien regresi sebesar 0,178. Hal ini menunjukkan bahwa model pembelajaran make a match secara langsung berpengaruh besar terhadap prestasi belajar siswa pada mata pelajaran IPS. Dengan penggunaan model pembelajaran make a match yang tepat, dapat meningkatkan prestasi belajar siswa kelas IX SMP Negeri 1 Karangploso pada mata pelajaran IPS.

3. Penerapan motivasi belajar secara signifikan mempengaruhi prestasi belajar siswa kelas IX SMP Negeri 1 Karangploso pada mata pelajaran IPS dengan koefisien regresi sebesar 0,351. Hal ini menunjukkan bahwa penerapan motivasi belajar siswa secara langsung berpengaruh besar terhadap prestasi belajar siswa kelas IX SMP Negeri 1 Karangploso pada mata pelajaran IPS.

4. Terdapat pengaruh interaksi yang signifikan antara model pembelajaran make a mach dan motivasi belajar terhadap prestasi belajar siswa kelas IX SMP Negeri 1 Karangploso pada mata pelajaran IPS. Hal ini menunjukkan bahwa prestasi belajar siswa pada mata pelajaran IPS dapat ditingkatkan melalui berbagai cara. Salah satu caranya melalui penerapan model pembelajaran make a match, penerapan motivasi belajar maupun dengan penerapan model pembelajaran make a match dan motivasi belajar secara bersamaan. 


\section{SARAN}

Berdasarkan hasil penelitian pengaruh penerapan model pembelajaran make a match dan motivasi belajar terhadap prestasi belajar IPS kelas IX SMP $\mathrm{N} 1$ Karangploso, ada beberapa saran terkait pembelajaran sebagai berikut.

1. Disarankan kepada guru untuk menggunakan berbagai metode pembelajaran agar siswa termotivasi dan hasil belajar meningkat. Model pembelajaran make a match memiliki pengaruh terhadap prestasi siswa.

2. Guru dapat meningkatkan prestasi belajar siswa dengan menggunakan beragam cara meningkatkan motivasi karena motivasi belajar berpengaruh terhadap hasil belajar.

\section{DAFTAR PUSTAKA}

Arikunto, Suharsimi. 2006. Prosedur Penelitian Suatu Pendekatan Praktis. Jakarta: Rineka Cipta.

Djamarah, Syaiful Bahri dan Aswan Zain. 2009. Strategi Belajar Mengajar. Jakarta: Rineka Cipta.

Hardiana, Vivi, Maskun, Suparman Arif. 2012. Pengaruh Model Pembelajaran Make a Match Terhadap Hasil Belajar IPS Terpadu. (Online) http://download.portalgaruda.org/article.php?article=287534\&val=7228\&title $=\mathrm{P}$ ENGARUH\%20MODEL\%20PEMBELAJARAN\%20MAKE\%20A\%20MATC H\%20TERHADAP\%20\%20HASIL \%20BELAJAR\%20IPS\%20TERPADU

Setyosari, Punaji. 2010. Metode Penelitian: Pendidikan dan Pengembangan. Jakarta: Prenadamedia Grup.

Solihatin, Etin dan Raharjo. 2007. Cooperative Learnig Analisis Model Pembelajaran IPS. Jakarta : Bumi Aksara.

Sugiyono. 2012. Metode Penelitian Kuantitatif, Kualitatif, dan R\&D. Bandung: Alfabeta.

Suprijono, Agus. 2009. Cooperative Learning Teori dan Aplikasi Paikem. Yogyakarta: Pustaka Pelajar.

Suryabrata, Sumadi. 2012. Metodologi Penelitan. Jakarta: PT Raja Grafindo.

Sutrisno, Hadi. 1998. Statistik 2.Yogyakarta: YPEP UGM.

Sutrisno, Hadi. 2001. Metodologi Research. Yogjakarta: Universitas Gajah Mada.

Syaiful dan Aswan. 2006. Strategi Belajar Mengajar. Jakarta: Rineka Cipta. 